\title{
Role of Different Sources of Nutrient Modules on Yield, Quality Parameters and Economics of Banana cv. Grand Naine
}

\author{
T. Ganapathi*, P.R. Dharmatti and Ramakrishna Hegde \\ Department of Horticulture, University of Agricultural Sciences, \\ Dharwad-580 005, Karnataka, India \\ *Corresponding author
}

\begin{tabular}{|l|}
\hline K e y w o r d s \\
Banana, INM, \\
Nutrient module, \\
$\begin{array}{l}\text { Soil properties and } \\
\text { NPK content in } \\
\text { plant }\end{array}$ \\
\hline Article Info \\
\hline $\begin{array}{l}\text { Accepted: } \\
\text { 14 December } 2017 \\
\text { Available Online: } \\
\text { 10 January } 2018\end{array}$ \\
\hline
\end{tabular}

A B S T R A C T
A field experiment was conducted at new orchard, Department of Horticulture, University of Agricultural Sciences, Dharwad during 2014-15 and 2015-16 on "Integrated nutrient management studies in banana cv. Grand Naine (AAA)" through application of different combination of organic manures and inorganic fertilizers with green manure, Azospirillum and PSB. The results revealed that, vermicompost equivalent to $40 \% \mathrm{RDN}(24.20 \mathrm{t} / \mathrm{ha})+$ Urea equivalent to $40 \% \operatorname{RDN}(535.73 \mathrm{~kg} / \mathrm{ha})+$ Green manure (sunnhemp @ $8.88 \mathrm{t} / \mathrm{ha})$ and Azospirillum (@30.86 kg/ha) equivalent to $20 \%$ RDN + PSB (@ $30.86 \mathrm{~kg} / \mathrm{ha}$ ) $\left(\mathrm{T}_{7}\right.$ ) recorded the highest yield parameters \{bunch weight $(26.94 \mathrm{~kg})$, number of hands per bunch (11.75), finger weight $(137.38 \mathrm{~g})$, finger length $(17.75 \mathrm{~cm})$, plot yield $(85.57 \mathrm{~kg})$ and the yield per ha $(66.02 \mathrm{t})\}$, quality parameters $\left\{\right.$ TSS $\left(23.52^{0}\right.$ brix $)$, total sugars $(20.30$ $\%)$, reducing sugars $(20.30 \%)$, non-reducing sugars $(17.87 \%)$, pulp to peel ratio (3.81), shelf life (6.33 days), the least starch $(3.67 \%)$ and titrable acidity $(0.25 \%)\}$ and gross returns (Rs.4.97 lakh/ha) and moderate net returns (Rs.3.04 lakh/ha) followed by $\mathrm{T}_{10}$ (Agrigold combination) and $\mathrm{T}_{11}$ (Bhumilabh combination). The highest net returns \{Rs.3.17 lakh/ha\} was recorded in $\mathrm{T}_{10}$ (Agrigold combination) followed by $\mathrm{T}_{7}$ (Rs.3.04 lakh/ha). However, the B: C ratio was highest in control $\left(\mathrm{T}_{12}, 3.42\right)$.

\section{Introduction}

In India, banana is cultivated in an area of 0.83 million ha with a production of 30 million tonnes (Anon., 2011).

The major banana growing areas are in Tamil Nadu, Maharashtra, Andhra Pradesh, Gujarat, Kerala, Karnataka, West Bengal and Orissa. It is being grown in an area of 1.12 lakh ha with a production of 2.28 lakh tonnes in Karnataka state.
Banana is known to consume more nutrients for its growth, yield and biomass production (Hazarika et al., 2015).

The use of chemical fertilizers alone has deleterious effect on soil physical, chemical and biological properties and productivity in the long run. The availability of organic manures is also one of the limitations for use in banana production. To fulfil the nutrient requirement only through organic or inorganic or bio- fertilizers alone is seldom possible but 
integration of all these sources will not only aid in achieving higher yield and quality but also in sustaining the soil fertility status in the long run.

\section{Materials and Methods}

The field experiment with an integrated nutrient module consisting of organic manures, chemical fertilizers, green manure and bio-fertilizer in banana cv. Grand Naine was conducted during 2014-15 and 2015-16 at new orchard, Department of Horticulture, University of Agricultural Sciences, Dharwad. The soil type was red with clay texture.

The experiment consists of 12 treatments viz.

\section{Plant crop}

$\mathrm{T}_{1-}$ FYM equivalent to $40 \% \mathrm{RDN}$ (48.40 t/ha) + VC equivalent to $40 \% \mathrm{RDN}(24.20 \mathrm{t} / \mathrm{ha})+$ GM (Sunnhemp @ 8.88 t/ha) and Azospirillum $(30.86 \mathrm{~kg} / \mathrm{ha})$ equivalent to $20 \% \mathrm{RDN}+\mathrm{PSB}$ (30.86 kg/ha).

$\mathrm{T}_{2}$-FYM equivalent to $40 \% \mathrm{RDN}$ (48.40 t/ha) + PM equivalent to $40 \% \operatorname{RDN}(8.96 \mathrm{t} / \mathrm{ha})+$ GM (Sunnhemp @ 8.88 t/ha) and Azospirillum (30.86 kg/ha) equivalent to $20 \% \mathrm{RDN}+\mathrm{PSB}$ (30.86 kg/ha).

$\mathrm{T}_{3-}$ FYM equivalent to $40 \% \mathrm{RDN}$ (48.40 t/ha) + SM equivalent to $40 \% \mathrm{RDN}(10.17 \mathrm{t} / \mathrm{ha})+$ GM (Sunnhemp @ 8.88 t/ha) and Azospirillum $(30.86 \mathrm{~kg} / \mathrm{ha})$ equivalent to $20 \% \mathrm{RDN}+\mathrm{PSB}$ (30.86 kg/ha).

$\mathrm{T}_{4-}$ FYM equivalent to $40 \% \mathrm{RDN}(48.40 \mathrm{t} / \mathrm{ha})$ + AG equivalent to $40 \% \mathrm{RDN}(10.52 \mathrm{t} / \mathrm{ha})+$ GM (Sunnhemp @ 8.88 t/ha) and Azospirillum $(30.86 \mathrm{~kg} / \mathrm{ha})$ equivalent to $20 \% \mathrm{RDN}+\mathrm{PSB}$ (30.86 kg/ha).

$\mathrm{T}_{5-}$ FYM equivalent to $40 \% \mathrm{RDN}$ (48.40 t/ha) $+\mathrm{BL}$ equivalent to $40 \% \mathrm{RDN}(7.56 \mathrm{t} / \mathrm{ha})+$
GM (Sunnhemp @ 8.88 t/ha) and Azospirillum (30.86 kg/ha) equivalent to $20 \% \mathrm{RDN}+\mathrm{PSB}$ (30.86 kg/ha).

$\mathrm{T}_{6-}$ FYM equivalent to $40 \% \mathrm{RDN}$ (48.40 t/ha) $+40 \%$ RDN through chemical fertilizer (Urea 535.73 kg/ ha) + GM (Sunnhemp @ 8.88 t/ha) and Azospirillum (30.86 kg/ha) equivalent to $20 \% \mathrm{RDN}+\mathrm{PSB}(30.86 \mathrm{~kg} / \mathrm{ha})$.

$\mathrm{T}_{7-} \mathrm{VC}$ equivalent to $40 \% \mathrm{RDN}(24.20 \mathrm{t} / \mathrm{ha})+$ $40 \%$ RDN through chemical fertilizer (Urea $535.73 \mathrm{~kg} / \mathrm{ha})+\mathrm{GM}$ (Sunnhemp @ $8.88 \mathrm{t} / \mathrm{ha})$ and Azospirillum (30.86 kg/ha) equivalent to $20 \% \mathrm{RDN}+\mathrm{PSB}(30.86 \mathrm{~kg} / \mathrm{ha})$.

$\mathrm{T}_{8-} \mathrm{PM}$ equivalent to $40 \% \mathrm{RDN}(8.96 \mathrm{t} / \mathrm{ha})+$ $40 \%$ RDN through chemical fertilizer (Urea $535.73 \mathrm{~kg} / \mathrm{ha})+\mathrm{GM}$ (Sunnhemp @ $8.88 \mathrm{t} / \mathrm{ha})$ and Azospirillum (30.86 kg/ha) equivalent to $20 \% \mathrm{RDN}+\mathrm{PSB}(30.86 \mathrm{~kg} / \mathrm{ha})$.

$\mathrm{T}_{9-} \mathrm{SM}$ equivalent to $40 \% \mathrm{RDN}(10.17 \mathrm{t} / \mathrm{ha})+$ $40 \% \mathrm{RDN}$ through chemical fertilizer (Urea $535.73 \mathrm{~kg} / \mathrm{ha})+\mathrm{GM}$ (Sunnhemp @ $8.88 \mathrm{t} / \mathrm{ha})$ and Azospirillum (30.86 kg/ha) equivalent to $20 \% \mathrm{RDN}+\mathrm{PSB}(30.86 \mathrm{~kg} / \mathrm{ha})$.

$\mathrm{T}_{10-} \mathrm{AG}$ equivalent to $40 \% \mathrm{RDN}(10.52 \mathrm{t} / \mathrm{ha})$ $+40 \%$ RDN through chemical fertilizer (Urea $535.73 \mathrm{~kg} / \mathrm{ha})+$ GM (Sunnhemp @ 8.88 t/ha) and Azospirillum (30.86 kg/ha) equivalent to $20 \% \mathrm{RDN}+\mathrm{PSB}(30.86 \mathrm{~kg} / \mathrm{ha})$

$\mathrm{T}_{11 \text { - }} \mathrm{BL}$ equivalent to $40 \% \mathrm{RDN}(7.56 \mathrm{t} / \mathrm{ha})+$ $40 \%$ RDN through chemical fertilizer (Urea $535.73 \mathrm{~kg} / \mathrm{ha})+\mathrm{GM}$ (Sunnhemp @ $8.88 \mathrm{t} / \mathrm{ha}$ ) and Azospirillum (30.86 kg/ha) equivalent to $20 \% \mathrm{RDN}+\mathrm{PSB}(30.86 \mathrm{~kg} / \mathrm{ha})$

$\mathrm{T}_{12}$-Control (RDF 200: 100: $300 \mathrm{~g}$ NPK /plant or 617.20:308.60: 925.80 kg NPK/ha + Farm yard manure@ 40 t/ha)

The recommended dose of phosphorous and potash $(100 \mathrm{~g} / \mathrm{plant}$ and $300 \mathrm{~g} / \mathrm{plant}$ 
respectively) was supplied through DAP and MOP.

\section{Ratoon crop}

$\mathrm{RDF}=100: 50: 100 \mathrm{NPK} \mathrm{g} /$ plant or 308.60:154.20: 308.60 kg NPK/ha) +FYM @ $20 \mathrm{t} / \mathrm{ha}$

Note: 1) FYM- Farm Yard Manure, VCVermicompost, PM-Poultry Manure, SMSheep Manure, AG-Agrigold, BL-Bhumilabh, GM-Green manure, PSB-Phosphate Solubilizing bacteria. Azospirillum (ACD-15) and PSB (Pseudomonas striata) were used for the study.

The application of organic manures, chemical fertilizers with green manure and bio-fertilizer will compensate the majority of the plant nutrition thereby increase the productivity of banana cv. Grand Naine. The influence was assessed on yield, quality and economics of banana. The results of the field experiments conducted during the year 2014-15 and 201516 are pooled and discussed.

\section{Results and Discussion}

The results of the field experiments conducted during the year 2014-15 and 2015-16 are pooled and discussed under different headings.

Effect of different sources of nutrient modules on yield parameters of banana (Table 1)

The influence of different sources of nutrient modules on yield parameters which caused the yield variations are discussed here under. The pooled data indicated that, the maximum mean yield of banana per hectare (66.02 t/ha) was recorded in $\mathrm{T}_{7}$ \{Vermicompost equivalent to $40 \%$ RDN (24.20 t/ha) + Chemical fertilizer (Urea $535.73 \mathrm{~kg} / \mathrm{ha}$ ) equivalent to $40 \% \mathrm{RDN}$ + Green manure (Sunnhemp @ 8.88 t/ha) +
Azospirillum (30.86 kg/ha) equivalent to $20 \%$ RDN + PSB (30.86 kg/ha) $\}$ which was on par with $T_{1}, T_{10}$ and $T_{11}$ and significantly superior over rest of the treatments (Table 1).

The highest mean yield of banana in $\mathrm{T}_{7}$ was attributed to the higher growth and yield contributing parameters. The mean yield components of banana indicated that the maximum bunch weight $(26.94 \mathrm{~kg})$, number of hands per bunch (11.75), finger weight $(137.38 \mathrm{~g})$, finger length $(17.75 \mathrm{~cm})$, number of fingers on third hand (16.93) were recorded in plants applied with vermicompost equivalent to $40 \% \operatorname{RDN}(24.20$ t/ha $)+$ Chemical fertilizer (Urea $535.73 \mathrm{~kg} / \mathrm{ha}$ ) equivalent to $40 \% \mathrm{RDN}+$ Green manure (sunnhemp @ 8.88 t/ha) and Azospirillum $(30.86 \mathrm{~kg} / \mathrm{ha})$ equivalent to $20 \% \mathrm{RDN}+\mathrm{PSB}$ (30.86 kg/ha) $\left(\mathrm{T}_{7}\right)$ (Table 1).

The similar results were also recorded with integrated nutrient modules by many scientists in banana. Athani et al., (1999) reported that, maximum number of fingers per bunch, bunch weight $(5.10 \mathrm{~kg} / \mathrm{bunch})$ and finally fruit yield (15.14 t/ha) was obtained by applying $50 \%$ $\mathrm{RDF}+$ vermicompost $2.00 \mathrm{~kg} / \mathrm{plant}$ in Rajapuri banana. They also reported that, organic matter in the form of vermicompost in combination with inorganic fertilizers increased the yield in banana cv. Rajapuri. Nachegowda et al., (2004) reported that, plants applied with $15 \mathrm{~kg}$ FYM + 180:108:220g NPK/plant/year recorded the highest bunch weight $(49.47 \mathrm{~kg})$, fruit length $(25.19 \mathrm{~cm})$, fruit weight $(220.21 \mathrm{~g})$, finger/hand (19.00), fingers/bunch (227.94) and the yield (148.41t/ha) in banana followed by $2.5 \mathrm{~kg}$ Sheep manure +108:108:2205g NPK/ plant/year. Hazarika et al., (2011) reported that, the highest number of fingers per hand (22.87), finger length $(22.97 \mathrm{~cm})$, circumference $(14.13 \mathrm{~cm})$, finger volume (282.98 cc) and weight of finger $(231.67 \mathrm{~g})$ were significantly influenced by $100 \%$ RDF 
+VAM (50 g/plant) + Azospirillum (50 $\mathrm{g} / \mathrm{plant})+$ PSB (50 g/plant) + Trichoderma harjianum $(50 \mathrm{~g} / \mathrm{plant})$ in banana.

Patil and Shinde (2013) recorded the highest bunch weight of $19.31 \mathrm{~kg}$ in plants inoculated with $75 \% \mathrm{RDF}+\mathrm{FYM}+$ Azotobacter (50 $\mathrm{g} /$ plant $)+$ PSB (50 g/plant) + VAM (250 $\mathrm{g}$ /plant) in Ardhapuri cultivar of banana. They also reported that, the highest yield of 85.80 t/ha obtained when the plants were treated with $50 \% \mathrm{RDF}+\mathrm{FYM}+$ Azatobacter (50 $\mathrm{g} /$ plant $)+$ PSB (50 g/plant) + VAM (250 g/plant) in banana cv. Ardhapuri (AAA). Significant increase in number of fingers per bunch and average bunch weight of $5.0 \mathrm{~kg}$ by applying vermicompost $+\mathrm{N}$ as inorganic fertilizer in banana reported by Manivannan and Selvamani (2014). They also reported that, maximum bunch weight, more number of fingers per bunch was obtained by applying vermicompost as full $\mathrm{N}$ in banana. They also opined that, significantly more finger weight, finger girth was obtained by applying organic + inorganic fertilizers. The maximum number of fingers per bunch, bunch weight (5.10 $\mathrm{kg} / \mathrm{bunch})$ and finally fruit yield (15.14 t/ha) by applying $50 \% \mathrm{RDF}+$ vermicompost 2.00 $\mathrm{kg} / \mathrm{plant}$ in banana.

\section{Influence of different sources of nutrient modules on quality parameters (Table 2)}

The mean of the pooled data indicated that, the quality parameters like Total Soluble Solids, Reducing sugars, Non reducing sugars, Total Sugars, Pulp to peel ratio and Shelf life was maximum $\left(23.52^{0} \mathrm{~B}, 17.87 \%, 2.43 \%\right.$, $20.31 \%, 3.81$ and 6.33 days respectively) in banana fruits harvested from plants treated with $\mathrm{T}_{7}$ \{Vermicompost equivalent to $40 \%$ RDN (24.20 t/ha) + $40 \%$ RDN through chemical fertilizer (urea $535.73 \mathrm{~kg} / \mathrm{ha}$ ) + Green manure (sunnhemp @ 8.88 t/ha) and Azospirillum $(30.86 \mathrm{~kg} / \mathrm{ha}$ ) equivalent to $20 \%$ RDN + PSB (30.86 kg/ha)\}. Whereas, the least titratable acidity $(0.25 \%)$ was recorded in $\mathrm{T}_{7}$ and $\mathrm{T}_{10}$ treatments followed by $\mathrm{T}_{11}$ treatment. However, the starch was least (3.67 $\%)$ in $\mathrm{T}_{7}$ and $\mathrm{T}_{10}$ treatments. In general the fruit quality parameters were improved in integrated nutrient modules compared to organic treatments (Table 2).

The main changes in fruit pulp during ripening are the conversion of starch to sugars. As ripening proceeds, pulp to peel ratio was increased from 2.0 in stage 5 to 2.7 in stage 7 when the fruits become fully ripened. This could be due to the osmotic transfer of moisture from the peel to the pulp as sugar content of pulp increased. It has been suggested that pulp to peel ratio can be considered as a coefficient of ripeness. These changes during ripening period (loss of greenness and increase in yellowness) may occur as a result of the breakdown of the chlorophyll in the peel tissue.

Venkatesh (1995) observed that application of organic manures viz., vermicompost (@ 4 t/ha) and farmyard manure (@ 2.5 t/ha) resulted in significantly higher amount of total sugars and decreased titratable acidity compared to inorganic fertilizers in grape. The results of present study also indicated the same. The results indicated that a progressive increase in total sugar content and decrease in starch content was observed during ripening. Thompson (1996) reported that the softening of banana fruit during ripening is associated with the conversion of starch to sugar, breakdown of pectin substances and the movement of water from rind of banana to the pulp and this could be the major cause for decreasing the various mechanical properties of banana during ripening. Ushakumari et al., (1997) recorded similar results as that of present study. They obtained significantly more reducing sugar by applying vermicompost as full $\mathrm{N}$ in banana cv. Njalipoovan. 
Table.1 Influence of different sources of nutrient modules on yield parameters in banana cv. Grand Naine (Pooled mean)

\begin{tabular}{|c|c|c|c|c|c|c|c|}
\hline Treatments & $\begin{array}{c}\text { Bunch weight. } \\
\text { (kg) }\end{array}$ & $\begin{array}{l}\text { No. of hands } \\
\text { per bunch }\end{array}$ & $\begin{array}{c}\text { Finger weight. } \\
\text { (g) }\end{array}$ & $\begin{array}{l}\text { Finger length } \\
\text { (cm) }\end{array}$ & $\begin{array}{l}\text { No. of Fingers on } \\
3^{\text {rd }} \text { hand }\end{array}$ & Plot yield (kg) & Yield (t/ha) \\
\hline$T_{1}$ & 18.17 & 10.06 & 124.27 & 16.14 & 14.89 & 73.21 & 56.48 \\
\hline $\mathbf{T}_{2}$ & 14.58 & 9.10 & 117.77 & 15.23 & 13.88 & 60.44 & 46.63 \\
\hline $\mathbf{T}_{3}$ & 11.55 & 8.58 & 104.28 & 14.36 & 13.10 & 58.35 & 45.02 \\
\hline $\mathbf{T}_{4}$ & 17.85 & 10.31 & 123.43 & 15.32 & 14.26 & 72.72 & 56.10 \\
\hline $\mathbf{T}_{5}$ & 16.41 & 9.73 & 120.39 & 15.55 & 14.19 & 70.04 & 54.04 \\
\hline$T_{6}$ & 19.18 & 10.02 & 129.53 & 16.12 & 15.02 & 70.52 & 54.40 \\
\hline $\mathbf{T}_{7}$ & 26.94 & 11.75 & 137.38 & 17.75 & 16.93 & 85.57 & 66.02 \\
\hline$T_{8}$ & 12.85 & 9.54 & 104.43 & 14.40 & 13.09 & 61.69 & 47.59 \\
\hline $\mathbf{T}_{9}$ & 19.54 & 10.19 & 129.83 & 16.12 & 15.04 & 70.83 & 54.64 \\
\hline $\mathbf{T}_{10}$ & 23.69 & 10.98 & 135.91 & 17.18 & 16.12 & 84.27 & 65.01 \\
\hline $\mathrm{T}_{11}$ & 22.51 & 10.49 & 135.16 & 17.07 & 16.14 & 73.66 & 56.83 \\
\hline$T_{12}$ & 19.17 & 9.70 & 128.02 & 16.66 & 15.68 & 71.21 & 54.94 \\
\hline S Em+/- & 0.65 & 0.15 & 1.84 & 0.31 & 0.30 & 4.28 & 3.30 \\
\hline $\mathrm{CD}$ at $5 \%$ & 1.91 & 0.44 & 5.39 & 0.90 & 0.87 & 12.55 & 9.68 \\
\hline
\end{tabular}

T. FYM equivalent to 40 \% RDN (48.40 t/ha) + VC equivalent to 40 \% RDN (24.20 t/ha) + GM (sunnhemp @ 8.88 t/ha) and Azospirillum (@ 30.86 kg/ha) equivalent to $20 \%$ RDN + PSB (@ 30.86 $\mathrm{kg} / \mathrm{ha})$.

T2-FYM equivalent to 40 \% RDN (48.40 t/ha) + PM equivalent to 40 \% RDN (8.96 t/ha) + GM (sunnhemp @ 8.88 t/ha) and Azospirillum (@ 30.86 kg/ha) equivalent to 20\% RDN + PSB (@ 30.86 $\mathrm{kg} / \mathrm{ha})$.

$\mathrm{T}_{3-}$ FYM equivalent to 40 \% RDN (48.40 t/ha) + SM equivalent to 40 \% RDN (10.17 t/ha) + GM (sunnhemp @ 8.88 t/ha) and Azospirillum (@ 30.86 kg/ha) equivalent to $20 \%$ RDN + PSB (@ 30.86 $\mathrm{kg} / \mathrm{ha}$ ).

T. FYM equivalent to 40 \% RDN (48.40 t/ha) + AG equivalent to 40 \% RDN (10.52 t/ha) + GM (sunnhemp @ 8.88 t/ha) and Azospirillum (@ 30.86 kg/ha) equivalent to $20 \%$ RDN + PSB (@ 30.86 $\mathrm{kg} / \mathrm{ha})$.

T5. FYM equivalent to 40 \% RDN (48.40 t/ha) + BL equivalent to 40 \% RDN (7.56 t/ha) + GM (Sunnhemp @ 8.88 t/ha) and Azospirillum (@ 30.86 kg/ha) equivalent to $20 \%$ RDN + PSB (@ 30.86 $\mathrm{kg} / \mathrm{ha})$.

$\mathrm{T}_{6}$ FYM equivalent to $40 \%$ RDN (48.40 t/ha) + 40 \% RDN through chemical fertilizer (urea 535.73 kg/ ha) + GM (sunnhemp @ 8.88 t/ha) and Azospirillum (@ 30.86 kg/ha) equivalent to $20 \%$ RDN + PSB (@ $30.86 \mathrm{~kg} / \mathrm{ha})$.

T7. VC equivalent to $40 \%$ RDN (24.20 t/ha) + 40 \% RDN through chemical fertilizer (urea $535.73 \mathrm{~kg} / \mathrm{ha}$ ) + GM (sunnhemp@ 8.88 t/ha) and Azospirillum (@ $30.86 \mathrm{~kg} / \mathrm{ha}$ ) equivalent to $20 \%$ RDN + PSB (@ $30.86 \mathrm{~kg} / \mathrm{ha})$.

$\mathrm{T}_{8 \text { - }}$ PM equivalent to $40 \%$ RDN (8.96 t/ha)+ $40 \%$ RDN through chemical fertilizer (urea $535.73 \mathrm{~kg} / \mathrm{ha}$ ) + GM (sunnhemp @ 8.88 t/ha) and Azospirillum (@ $30.86 \mathrm{~kg} / \mathrm{ha}$ ) equivalent to $20 \%$ RDN + PSB (@30.86 kg/ha).

T. SM equivalent to $40 \%$ RDN (10.17 t/ha) + 40 \% RDN through chemical fertilizer (urea $535.73 \mathrm{~kg} / \mathrm{ha}$ ) + GM (sunnhemp @ $8.88 \mathrm{t} / \mathrm{ha})$ and Azospirillum (@ $30.86 \mathrm{~kg} / \mathrm{ha}$ ) equivalent to $20 \% \mathrm{RDN}+$ PSB (@30.86 kg/ha).

$\mathrm{T}_{10}$ - AG equivalent to $40 \% \mathrm{RDN}$ (10.52 t/ha) + 40 \% RDN through chemical fertilizer (urea $535.73 \mathrm{~kg} / \mathrm{ha}$ ) + GM (sunnhemp @ 8.88 t/ha) and Azospirillum (@ $30.86 \mathrm{~kg} / \mathrm{ha}$ ) equivalent to 20\% RDN + PSB (@30.86 kg/ha

$\mathrm{T}_{11}$. BL equivalent to $40 \% \mathrm{RDN}$ (7.56 t/ha) + $40 \%$ RDN through chemical fertilizer (urea $535.73 \mathrm{~kg} / \mathrm{ha}$ ) + GM (sunnhemp @ 8.88 t/ha) and Azospirillum (@ $30.86 \mathrm{~kg} / \mathrm{ha}$ ) equivalent to $20 \% \mathrm{RDN}+$ PSB (@ $30.86 \mathrm{~kg} / \mathrm{ha})$

$\mathrm{T}_{12}$-Control (RDF=617.20:308.60: $925.80 \mathrm{~kg} \mathrm{NPK} / \mathrm{ha}+$ Farm yard manure@ $40 \mathrm{t} / \mathrm{ha}$ (plant crop)

Ratoon crop: RDF=308.60:154.20: 308.60 kg NPK/ha) + FYM @ 20/ha accordingly it has been supplied through different sources

FYM- Farmyard manure, VC-Vermicompost, PM-Poultry manure, SM-Sheep manure, AG-Agrigold, BL-Bhumilabh, GM-Green manure, PSB-Phosphate Solubilizing bacteria 
Table.2 Influence of different sources of nutrient modules on quality parameters in banana cv. Grand Naine (Pooled mean)

\begin{tabular}{|c|c|c|c|c|c|c|c|c|}
\hline Treatments & $\begin{array}{c}\text { TSS } \\
\left({ }^{0} \text { brix }\right)\end{array}$ & $\begin{array}{c}\text { Total Sugars } \\
(\%)\end{array}$ & $\begin{array}{l}\text { RS } \\
(\%)\end{array}$ & $\begin{array}{l}\text { NRS } \\
(\%)\end{array}$ & $\begin{array}{c}\text { Starch } \\
(\%)\end{array}$ & $\begin{array}{c}\text { Titrable acidity } \\
(\%)\end{array}$ & $\begin{array}{l}\text { Pulp to } \\
\text { peel ratio }\end{array}$ & $\begin{array}{l}\text { Shelf life } \\
\text { (Days) }\end{array}$ \\
\hline $\mathbf{T}_{1}$ & 19.82 & 18.95 & 16.92 & 2.03 & 5.00 & 0.33 & 3.25 & 5.04 \\
\hline $\mathbf{T}_{2}$ & 19.46 & 18.25 & 16.55 & 1.70 & 5.74 & 0.36 & 2.78 & 4.55 \\
\hline$T_{3}$ & 19.02 & 17.88 & 16.31 & 1.57 & 6.08 & 0.37 & 2.55 & 4.53 \\
\hline $\mathbf{T}_{4}$ & 19.54 & 18.57 & 16.80 & 1.77 & 5.00 & 0.33 & 3.12 & 5.04 \\
\hline $\mathbf{T}_{5}$ & 19.70 & 18.76 & 16.97 & 1.80 & 5.17 & 0.33 & 3.04 & 4.76 \\
\hline$T_{6}$ & 21.45 & 19.49 & 17.30 & 2.19 & 4.33 & 0.29 & 3.47 & 5.41 \\
\hline $\mathbf{T}_{7}$ & 23.52 & 20.30 & 17.87 & 2.43 & 3.67 & 0.25 & 3.81 & 6.33 \\
\hline $\mathrm{T}_{8}$ & 19.13 & 17.52 & 15.98 & 1.54 & 6.21 & 0.39 & 2.46 & 4.12 \\
\hline$T_{9}$ & 20.25 & 19.07 & 17.03 & 2.04 & 4.92 & 0.32 & 3.33 & 5.38 \\
\hline$T_{10}$ & 22.23 & 20.10 & 17.71 & 2.39 & 3.67 & 0.25 & 3.74 & 5.80 \\
\hline$T_{11}$ & 22.07 & 19.31 & 17.09 & 2.22 & 3.84 & 0.28 & 3.56 & 5.68 \\
\hline$T_{12}$ & 20.57 & 19.13 & 16.98 & 2.15 & 4.48 & 0.32 & 3.35 & 5.46 \\
\hline S Em+/- & 0.20 & 0.39 & 0.39 & 0.02 & 0.05 & 0.00 & 0.04 & 0.08 \\
\hline CD at $5 \%$ & 0.58 & 1.15 & 1.13 & 0.06 & 0.16 & 0.01 & 0.10 & 0.24 \\
\hline
\end{tabular}

T 1 FYM equivalent to $40 \%$ RDN (48.40 t/ha) + VC equivalent to $40 \%$ RDN (24.20 t/ha) + GM (sunnhemp @ 8.88 t/ha) and Azospirillum (@ 30.86 kg/ha) equivalent to $20 \%$ RDN + PSB (@ 30.86 $\mathrm{kg} / \mathrm{ha}$.

$\mathrm{T}_{2}$-FYM equivalent to $40 \%$ RDN (48.40 t/ha) + PM equivalent to $40 \%$ RDN (8.96 t/ha)+ GM (sunnhemp @ 8.88 t/ha) and Azospirillum (@ 30.86 kg/ha) equivalent to $20 \%$ RDN + PSB (@ 30.86 $\mathrm{kg} / \mathrm{ha})$.

T3- FYM equivalent to 40 \% RDN (48.40 t/ha) + SM equivalent to 40 \% RDN (10.17 t/ha) + GM (sunnhemp @ 8.88 t/ha) and Azospirillum (@30.86 kg/ha) equivalent to 20 \% RDN + PSB (@ 30.86

T. FYM equivalent to 40 \% RDN (48.40 t/ha) + AG equivalent to 40 \% RDN (10.52 t/ha) + GM (sunnhemp @ 8.88 t/ha) and Azospirillum (@ 30.86 kg/ha) equivalent to $20 \%$ RDN + PSB (@ 30.86 $\mathrm{T}_{4 .} \mathrm{FY}$

T5- FYM equivalent to 40 \% RDN (48.40 t/ha) + BL equivalent to 40 \% RDN (7.56 t/ha) + GM (Sunnhemp @ 8.88 t/ha) and Azospirillum (@ 30.86 kg/ha) equivalent to 20\% RDN + PSB (@ 30.86 $\mathrm{kg} / \mathrm{ha})$.

$\mathrm{T}_{6}$ FYM equivalent to $40 \%$ RDN (48.40 t/ha) + 40 \% RDN through chemical fertilizer (urea $535.73 \mathrm{~kg} / \mathrm{ha}$ ) + GM (sunnhemp @ 8.88 t/ha) and Azospirillum (@ $30.86 \mathrm{~kg} / \mathrm{ha}$ ) equivalent to 20\% RDN + PSB (@ $30.86 \mathrm{~kg} / \mathrm{ha})$.

T 7. VC equivalent to $40 \%$ RDN (24.20 t/ha) + $40 \%$ RDN through chemical fertilizer (urea $535.73 \mathrm{~kg} / \mathrm{ha}$ ) + GM (sunnhemp@ 8.88 t/ha) and Azospirillum (@ $30.86 \mathrm{~kg} / \mathrm{ha}$ ) equivalent to 20 \% RDN + PSB (@30.86 kg/ha).

$\mathrm{T}_{8 \text { - }}$ PM equivalent to $40 \% \mathrm{RDN}$ (8.96 t/ha)+ 40 \% RDN through chemical fertilizer (urea $535.73 \mathrm{~kg} / \mathrm{ha}$ ) + GM (sunnhemp @ 8.88 t/ha) and Azospirillum (@ $\left.30.86 \mathrm{~kg} / \mathrm{ha}\right)$ equivalent to $20 \% \mathrm{RDN}+$ PSB (@ $30.86 \mathrm{~kg} / \mathrm{ha})$.

T. SM equivalent to $40 \%$ RDN (10.17 t/ha) + 40 \% RDN through chemical fertilizer (urea $535.73 \mathrm{~kg} / \mathrm{ha}$ ) + GM (sunnhemp @ 8.88 t/ha) and Azospirillum (@ $30.86 \mathrm{~kg} / \mathrm{ha}$ ) equivalent to $20 \%$ RDN + PSB (@ $30.86 \mathrm{~kg} / \mathrm{ha})$.

$\mathrm{T}_{10}$ - AG equivalent to $40 \% \mathrm{RDN}(10.52 \mathrm{t} / \mathrm{ha})+40 \% \mathrm{RDN}$ through chemical fertilizer (urea $\left.535.73 \mathrm{~kg} / \mathrm{ha}\right)+\mathrm{GM}$ (sunnhemp @ 8.88 t/ha) and Azospirillum (@ $\left.30.86 \mathrm{~kg} / \mathrm{ha}\right)$ equivalent to $20 \% \mathrm{RDN}+$ PSB (@ $30.86 \mathrm{~kg} / \mathrm{ha}$

$\mathrm{T}_{11}$. BL equivalent to $40 \%$ RDN (7.56 t/ha) + 40 \% RDN through chemical fertilizer (urea $535.73 \mathrm{~kg} / \mathrm{ha}$ ) + GM (sunnhemp @ 8.88 t/ha) and Azospirillum (@ $30.86 \mathrm{~kg} / \mathrm{ha}$ ) equivalent to $20 \%$ RDN + PSB (@30.86 kg/ha)

$\mathrm{T}_{12}$-Control (RDF=617.20:308.60: $925.80 \mathrm{~kg} \mathrm{NPK} / \mathrm{ha}+$ Farm yard manure@ $40 \mathrm{t} / \mathrm{ha}$ (plant crop)

Ratoon crop: RDF=308.60:154.20: 308.60 kg NPK/ha) + FYM @ 20/ha accordingly it has been supplied through different sources

FYM- Farmyard manure, VC-Vermicompost, PM-Poultry manure, SM-Sheep manure, AG-Agrigold, BL-Bhumilabh, GM-Green manure, PSB-Phosphate Solubilizing bacteria 
Table.3 Influence of different sources of nutrient modules on economics of cultivation of banana cv. Grand Naine

\begin{tabular}{|c|c|c|c|c|}
\hline Treatments & GC (Rs) & GR (Rs) & NR (Rs) & B:C ratio \\
\hline$T_{1}$ & $1,72,070$ & $4,25,377$ & $2,53,307$ & 2.45 \\
\hline $\mathbf{T}_{2}$ & $1,41,057$ & $3,51,422$ & $2,10,365$ & 2.49 \\
\hline $\mathbf{T}_{3}$ & $1,47,347$ & $3,39,108$ & $1,91,761$ & 2.30 \\
\hline $\mathbf{T}_{4}$ & $1,84,279$ & $4,22,733$ & $2,38,454$ & 2.29 \\
\hline $\mathbf{T}_{5}$ & $2,07,715$ & $4,06,747$ & $1,99,032$ & 1.96 \\
\hline$T_{6}$ & $1,68,454$ & $4,09,822$ & $2,41,368$ & 2.43 \\
\hline $\mathbf{T}_{7}$ & $1,92,654$ & $4,97,621$ & $3,04,967$ & 2.58 \\
\hline$T_{8}$ & $1,29,016$ & $3,58,638$ & $2,29,622$ & 2.78 \\
\hline $\mathbf{T}_{9}$ & $1,35,306$ & $4,11,605$ & $2,76,299$ & 3.04 \\
\hline $\mathbf{T}_{10}$ & $1,72,238$ & $4,90,095$ & $3,17,857$ & 2.85 \\
\hline$T_{11}$ & $1,95,674$ & $4,28,279$ & $2,32,605$ & 2.19 \\
\hline $\mathbf{T}_{12}$ & $1,21,164$ & $4,13,830$ & $2,92,667$ & 3.42 \\
\hline S Em+/- & - & 24394 & 24395 & 0.14 \\
\hline CD at $5 \%$ & - & 71546 & 71546 & 0.41 \\
\hline
\end{tabular}

Banana fruit selling price (Rs/t): plant crop Rs.8,000 and ratoon crop Rs.7,000

GC: Gross cost, GR: Gross returns, NR: Net returns and B:C ratio benefit : cost ratio

T. FYM equivalent to 40 \% RDN (48.40 t/ha) + VC equivalent to 40 \% RDN (24.20 t/ha) + GM (sunnhemp @ 8.88 t/ha) and Azospirillum (@30.86 kg/ha) equivalent to $20 \%$ RDN + PSB (@ 30.86 $\mathrm{kg} / \mathrm{ha})$.

T2-FYM equivalent to 40 \% RDN (48.40 t/ha) + PM equivalent to 40 \% RDN (8.96 t/ha) + GM (sunnhemp @ 8.88 t/ha) and Azospirillum (@ 30.86 kg/ha) equivalent to $20 \%$ RDN + PSB (@ 30.86 $\mathrm{kg} / \mathrm{ha}$ ).

T3- FYM equivalent to $40 \%$ RDN (48.40 t/ha) + SM equivalent to 40 \% RDN (10.17 t/ha) + GM (sunnhemp @ 8.88 t/ha) and Azospirillum (@ 30.86 kg/ha) equivalent to $20 \%$ RDN + PSB (@30.86 $\mathrm{kg} / \mathrm{ha})$.

T. FYM equivalent to 40 \% RDN (48.40 t/ha) + AG equivalent to 40 \% RDN (10.52 t/ha) + GM (sunnhemp @ 8.88 t/ha) and Azospirillum (@ 30.86 kg/ha) equivalent to $20 \%$ RDN + PSB (@30.86 $\mathrm{kg} / \mathrm{ha}$ ).

T5- FYM equivalent to 40 \% RDN (48.40 t/ha) + BL equivalent to 40 \% RDN (7.56 t/ha) + GM (Sunnhemp @ 8.88 t/ha) and Azospirillum (@ 30.86 kg/ha) equivalent to 20\% RDN + PSB (@ 30.86 $\mathrm{kg} / \mathrm{ha})$.

$\mathrm{T}_{6}$ FYM equivalent to $40 \% \mathrm{RDN}$ (48.40 t/ha) + $40 \%$ RDN through chemical fertilizer (urea $535.73 \mathrm{~kg} / \mathrm{ha}$ ) + GM (sunnhemp @ $8.88 \mathrm{t} / \mathrm{ha}$ ) and Azospirillum (@ $\left.30.86 \mathrm{~kg} / \mathrm{ha}\right)$ equivalent to $20 \% \mathrm{RDN}+$ PSB (@ $30.86 \mathrm{~kg} / \mathrm{ha})$.

$\mathrm{T}_{7}$. VC equivalent to $40 \% \mathrm{RDN}$ (24.20 t/ha) + $40 \%$ RDN through chemical fertilizer (urea $535.73 \mathrm{~kg} / \mathrm{ha}$ ) + GM (sunnhemp@ $8.88 \mathrm{t} / \mathrm{ha}$ ) and Azospirillum (@ $30.86 \mathrm{~kg} / \mathrm{ha}$ ) equivalent to $20 \%$ RDN + PSB (@30.86 kg/ha).

$\mathrm{T}_{8 \text { - }}$ PM equivalent to $40 \% \mathrm{RDN}(8.96 \mathrm{t} / \mathrm{ha})+40 \% \mathrm{RDN}$ through chemical fertilizer (urea $535.73 \mathrm{~kg} / \mathrm{ha}$ ) + GM (sunnhemp @ $\left.8.88 \mathrm{t} / \mathrm{ha}\right)$ and Azospirillum (@ $30.86 \mathrm{~kg} / \mathrm{ha}$ ) equivalent to $20 \% \mathrm{RDN}+$ PSB (@30.86 kg/ha).

T. SM equivalent to $40 \%$ RDN (10.17 t/ha) + $40 \%$ RDN through chemical fertilizer (urea $535.73 \mathrm{~kg} / \mathrm{ha}$ ) + GM (sunnhemp @8.88 t/ha) and Azospirillum (@ $30.86 \mathrm{~kg} / \mathrm{ha}$ ) equivalent to $20 \% \mathrm{RDN}+$ PSB (@30.86 kg/ha).

$\mathrm{T}_{10}$ - AG equivalent to $40 \% \mathrm{RDN}$ (10.52 t/ha) + $40 \%$ RDN through chemical fertilizer (urea 535.73 kg/ ha) + GM (sunnhemp @ 8.88 t/ha) and Azospirillum (@ 30.86 kg/ha) equivalent to 20\% RDN + PSB (@30.86 kg/ha

$\mathrm{T}_{11}$. BL equivalent to $40 \%$ RDN (7.56 t/ha) + $40 \%$ RDN through chemical fertilizer (urea $535.73 \mathrm{~kg} / \mathrm{ha}$ ) + GM (sunnhemp @ 8.88 t/ha) and Azospirillum (@ $30.86 \mathrm{~kg} / \mathrm{ha}$ ) equivalent to $20 \%$ RDN + PSB (@30.86 kg/ha)

$\mathrm{T}_{12}$-Control (RDF=617.20:308.60: $925.80 \mathrm{~kg} \mathrm{NPK/ha}+$ Farm yard manure@ $40 \mathrm{t} / \mathrm{ha}$ (plant crop)

Ratoon crop: RDF=308.60:154.20: $308.60 \mathrm{~kg} \mathrm{NPK/ha)} \mathrm{+} \mathrm{FYM} \mathrm{@} \mathrm{20/ha} \mathrm{accordingly} \mathrm{it} \mathrm{has} \mathrm{been} \mathrm{supplied} \mathrm{through} \mathrm{different} \mathrm{sources}$

FYM- Farmyard manure, VC-Vermicompost, PM-Poultry manure, SM-Sheep manure, AG-Agrigold, BL-Bhumilabh, GM-Green manure, PSB-Phosphate Solubilizing bacteria 
They also reported that significantly higher content of total sugar was obtained by applying vermicompost + inorganic fertilizers whereas, significantly less acidity was obtained by applying vermicompost + inorganic fertilizers and vermiculture in-situ and the highest content of non-reducing sugar by applying vermiculture in-situ. This could be due to the hydrolysis of starch into sugar during ripening (Garcia and Lajolo, 1988). Increase in TSS is an important trait of hydrolysis of starch in to soluble sugars such as glucose, sucrose and fructose (Stover and Simmonds, 1987 and Kulkarni et al., 2010).

Mustaffa et al., (2004) opined that application of $2.5 \mathrm{~kg}$ compost $+1.0 \mathrm{~kg}$ vermicompost + $1.0 \mathrm{~kg}$ neem cake $+2.5 \mathrm{~kg}$ poultry manure at 3,5 and 7 months after planting recorded the maximum TSS $\left(29.40^{\circ}\right.$ Brix and $32.20^{\circ}$ Brix respectively), acidity (0.59\% and $0.61 \%$ respectively), sugar - acid ratio (49.8 and 52.8 respectively), total sugars (25\% and $26.3 \%$ respectively) and low starch (3.2\% and $3.4 \%$ respectively). The lowest quality was recorded in inorganically fertilized fruits of Rasthali and Karpuravalli cultivars of banana respectively. Hazarika and Ansari (2008) revealed that bio-chemical constituents viz., TSS, reducing sugar, non-reducing sugar, ascorbic acid, and moisture content of fruits was significantly influenced by different treatments having organic manure and biofertilizer along with inorganic fertilizers except sugar-acid ratio and titratable acidity in banana cv. Jahaji (AAA).

The results of Tangaselvabai et al., (2009) were in line with the present study. They reported that the highest TSS, reducing sugars, non-reducing sugars, total sugars, ascorbic acid and starch was noticed in plants treated with 100:30:330 g NPK/plant in 2 splits + Azospirillum, $100: 30: 330 \mathrm{~g}$ $\mathrm{NPK} /$ plant in 2 splits + Azospirillum, 75:30:330 g NPK/plant in 2 splits +
Azospirillum, 220:30:330 g NPK/plant in 4 splits, 100:30:330 g NPK/plant in 2 splits + Azospirillum and 100:30:330 g NPK/plant in 2 splits+ Azospirillum respectively.

\section{Influence of different sources of nutrient modules on banana economics (Table 3 )}

Knowing a module for getting higher crop yield, maintaining soil health and use of naturally available farm resources and wastes is the need of the hour. Banana crop is an exhaustive commercial horticultural crop which is grown for two-to-three years from single planting. The nutrient management plays a major role in its cultivation. The nutrient module which fetches higher returns as well as on par benefit: cost ratio as that of highest returns and highest benefit: cost ratio can be adopted for cultivation of banana.

The pooled economic analysis of treatments revealed that the lowest gross cost (Rs.1.29 lakh/ha) was incurred in the treatment $\mathrm{T}_{8}$ \{Poultry manure equivalent to $40 \% \mathrm{RDN}$ $(8.96 \mathrm{t} / \mathrm{ha})+40 \% \mathrm{RDN}$ through chemical fertilizer (urea $535.73 \mathrm{~kg} / \mathrm{ha}$ ) + Green manure (sunnhemp@8.88 t/ha) and Azospirillum (30.86 kg/ha) equivalent to $20 \% \mathrm{RDN}+\mathrm{PSB}$ (30.86 kg/ha) . The treatment $\mathrm{T}_{7}$ \{Vermicompost equivalent to $40 \% \mathrm{RDN}$ $(24.20 \mathrm{t} / \mathrm{ha})+40 \% \mathrm{RDN}$ through chemical fertilizer (urea $535.73 \mathrm{~kg} / \mathrm{ha}$ ) + Green manure (sunnhemp @ 8.88 t/ha) and Azospirillum (30.86 kg/ha) equivalent to $20 \% \mathrm{RDN}+\mathrm{PSB}$ $(30.86 \mathrm{~kg} / \mathrm{ha})\}$ recorded the highest gross returns (Rs.4.97 lakh/ha). The highest net returns $\left\{\right.$ Rs.3.17 lakh/ha\} in $\mathrm{T}_{10}$ \{Agrigold equivalent to $40 \% \mathrm{RDN}(10.52 \mathrm{t} / \mathrm{ha})+40 \%$ RDN through chemical fertilizer (urea 535.73 $\mathrm{kg} / \mathrm{ha}$ ) + Green manure (sunnhemp @ 8.88 $\mathrm{t} / \mathrm{ha})$ and Azospirillum (30.86 kg/ha) equivalent to $20 \% \mathrm{RDN}+\mathrm{PSB}$ (30.86 $\mathrm{kg} / \mathrm{ha}$ ) \} followed by $\mathrm{T}_{7}$ (Rs.3.04 lakh/ha). The highest benefit: cost ratio (3.42) was recorded in $\mathrm{T}_{12}\{\mathrm{RDF}=617: 308.6: 925.8 \mathrm{~kg} \mathrm{NPK} / \mathrm{ha}$ ) 
+ Farmyard manure (@ 40.00 t/ha) followed by $\mathrm{T}_{9}, \mathrm{~T}_{10}, \mathrm{~T}_{8}$ and $\mathrm{T}_{7}(3.04,2.85,2.78$ and 2.58 respectively) treatments. The treatment $\mathrm{T}_{7}$ (vermicompost combination) recorded moderate net returns (3.04 lakh/ ha) and B: C ratio (2.58) and is considered to be good due to the fact that if vermicompost is produced by farmers themselves the $\mathrm{BC}$ ratio can also be improved.

Bhalerao et al., (2009) reported that application of $100 \%$ recommended dose of NPK with $10 \mathrm{~kg}$ FYM per plant and biofertilizers (Azospirillum and PSB at $25 \mathrm{~g}$ each per plant) was found beneficial in terms financial returns with highest benefit cost ratio (1.48) in banana cv. Grand Naine.

Tangaselvabai et al., (2009) also reported that treatment with 100:30:330 g NPK/plant in 2 splits + Azospirillum was found to be superior for increased net profit (Rs/ha) and benefit: cost ratio. The integrated nutrient modules would be superior in obtaining higher net profit and on par benefit: cost ratio as compared to the control treatment $(100 \%$ RDF + FYM).

Kuttimani et al., (2013b) reported that, higher gross returns of Rs. 3,63,850/- and Rs.3,85,600/- was recorded during 2010-11 and 2011-12 respectively with the application of 100 per cent recommended dose of fertilizer along with $40 \%$ Wellgro soil and the net return was higher (Rs. 2,25,403/- and Rs. 2,48,364/-) with the application of $100 \%$ recommended dose of fertilizer along with 40 $\%$ Well grow soil. The benefit-cost ratio was higher (2.63) with $40 \%$ Well grow soil +100 $\% \mathrm{RDF}$. The results of the present study also indicated higher gross returns when integrated nutrient modules were followed. However, the organic nutrient modules registered lesser gross returns owing to the fact that the banana crop is an exhaustive crop which might not be coped up by organics alone.
The cost of fertilizers is increasing enormously and the soil health is deteriorating by application of chemical fertilizers alone. So to maintain soil health and reduce the cost of cultivation application of recommended dose of nitrogen in integrated manner would be a better nutrient module. Application of plants with vermicompost equivalent to $40 \%$ $\mathrm{RDN}(24.20 \mathrm{t} / \mathrm{ha})+40 \% \mathrm{RDN}$ through chemical fertilizer (urea $535.73 \mathrm{~kg} / \mathrm{ha}$ ) + Green manure (sunnhemp @ 8.88 t/ha) and Azospirillum (30.86 kg/ha) equivalent to $20 \%$ $\mathrm{RDN}+\mathrm{PSB}$ (30.86 kg/ha) $\left(\mathrm{T}_{7}\right)$ was most superior in increasing yield and quality parameters besides reducing the crop duration. The treatment $\mathrm{T}_{7}$ recorded the highest gross returns (Rs.4.97 lakh/ha) and moderate net returns (Rs.3.04 lakh/ha). However, the $\mathrm{B}$ : $\mathrm{C}$ ratio was highest in control $\left(\mathrm{T}_{12}, 3.42\right)$. but still $\mathrm{T}_{7}$ is considered to be good due to the fact that, if vermicompost is produced by farmers the $\mathrm{BC}$ ratio can also be improved in $\mathrm{T}_{7}$ (vermicompost combination).

\section{References}

Anonymous, 2011. National Horticulture Board. Department of Agriculture and Cooperation, Ministry of Agriculture, Govt. of India, New Delhi.

Athani, S. I., Hulamanai, N. C. and Shirol, A.M., 1999. Effect of vermicompost on maturity and yield of banana cv. Rajapuri (Musa AAB). South Indian Hort. 47(1-6): 4-7.

Bhalerao, V. P., Patil, N. M., Badgujar, C. D. and Patil, D. R., 2009. Studies on integrated nutrient management for tissue cultured Grand Naine banana. Indian J. Agric. Res., 43 (2):107-112.

Garcia, E. and Lajolo, F. M., 1988. Starch transformation during banana ripening: the amylase and glucosidase behavior. J. Food Sci., 53: 1181-1188.

Hazarika, B. N. and Ansari, S., 2008. Effect 
of integrated nutrient management on quality

of banana cv. Jahaji (AAA). Indian

Agriculturist, 52(3/4): 175-178.

Hazarika, T. K., Bhattacharyya, R. K. and Nautiyal, B. P., 2015. Growth Parameters, Leaf Characteristics and Nutrient Status of Banana as Influenced by Organics, Bio-fertilizers and Bioagents. Journal of Plant Nutrition, 38 (8).

Hazarika, T. K., Nautiyal, B. P. and Bhattacharya, R. K., 2011. Effect of INM on productivity and soil characteristics of tissue cultured banana cv. Grand Naine in Mizoram, India. Indian J. Hort. 43(1): 30-35.

Kulkarni, S. G., Kudachikar, V.B. and Prakash, M. N., 2010. Studies on physico- chemical changes during artificial ripening of banana (Musa sp) variety 'Robusta'. J Food Sci Technol. (online journal DOI 10.1007/s13197010-0133-y)

Kuttimani, R., Velayudham, K., Somasundaram E. and Muthukrishnan, P. 2013b. Effect of integrated nutrient management on yield and economics of banana. Global Journal of Biology, Agriculture and Health Sciences, 2(4):191-195.

Manivannan, K., and Selvamani, P., 2014. Influence of organic inputs on the yield and quality of fruits in banana cultivar 'Poovan' (Syn. Mysore AAB). ISHS Acta Hortic. 1018.

Mustaffa, M. M., Kumar, V., Tanuja Priya, B. and Dhanasekhar, D., 2004. Influence of organic manure on growth and yield of banana. International congress on Musa: Harnessing research to improve livelihoods, Penang, Malaysia. 214: 6566.

Nachegowda V, Senthil Kumar K and Raghavendra Prasad G C 2004. Effect of organic and inorganic fertilizers on growth, yield and quality of tissue cultured banana cv. Robusta. Proceedings of National Seminar on Banana Industry - Present Scenario and Future Strategies held at BCKV, FTC, Kalyani, West Bengal, $11-13^{\text {th }}$ June, 2004.

Patil, V. K. and Shinde, B. N., 2013. Studies on integrated nutrient management on growth and yield of banana cv. Ardhapuri (Musa AAA). J. Hort. For., 5(9):130-138.

Stover, R. H. and Simmonds, N. W., 1987. Bananas. $3^{\text {rd }}$ Ed.; John, W. \& Sons Inc: New York. p. 256

Tangaselvabai, T., Gailice Leo Justin, C., Nirmal Johnson, S.B. and Jayasekhar, M., 2009. Influence of nutrients on qualitative and quantitative traits of banana. Indian J. Agric. Res. 43(4): 274-278.

Ushakumari, K., Prabhukumari, P. and Padmaja, P. 1997. Efficiency of vermicompost on yield and quality of banana (AB) cv. Njalipoovan. South Indian Hort., 49(3-4):158-160.

Venkatesh, 1995. Effect of vermiculture on soil composition, growth, yield and quality of Thomson seedless grapes (Vitis vinifera L.). M.Sc. (Agri.) Thesis University of Agricultural Sciences, Dharwad.

\section{How to cite this article:}

Ganapathi, T., P.R. Dharmatti and Ramakrishna Hegde. 2018. Role of Different Sources of Nutrient Modules on Yield, Quality Parameters and Economics of Banana cv. Grand Naine. Int.J.Curr.Microbiol.App.Sci. 7(01): 2013-2022. doi: https://doi.org/10.20546/ijcmas.2018.701.243 